\title{
Surviving Maria from Dominica: Memory, Displacement and Bittersweet Beginnings
} Adom Philogene Heron, Department of Anthropology, Goldsmiths College, University of London, New Cross, London, United Kingdom, SE14 6NW, A.heron@gold.ac.uk

\begin{abstract}
This paper refracts questions of human "resilience" through the prism of social relations. Herein, it asks how Caribbean people utilize interpersonal networks, patterns of sociality and kinship relations to mitigate the exigencies of increasingly violent hurricanes. The essay draws on the individual narratives of three Dominicans: a librarian who recollects moments of familial support during hurricane David of 1979; the post-Maria journey of dislocation of a young woman as she ventures through an extended kin network, finding herself adrift in East London, far from loved ones; and a teacher and mother, who finally gets her "papers" for America—reunited with her husband after years of waiting, yet, forced to leave her mother, father and siblings at home. These narratives chart the social debris of Maria, whilst illustrating the ambivalent routes people take to reassemble their lives. In turn, they present kinship togetherness amidst chaos; an uprooted life in waiting; and the sudden acceleration of a long-awaited familial migration. Hence, "resilience” is revealed as something that is ethnographically fraught with contradiction; ever incomplete and bittersweet. More broadly the paper complicates questions of "resilience” by offering an interpersonal ethnographic perspective that compliments the large-scale focus of most disaster scholarship.
\end{abstract}

Keywords: Dominica, flexibility, anthropocene, resilience, social relations 


\section{Prologue: A Timeline of a Storm}

September $18^{\text {th }}$ 2017. 10:00 p.m. London, England. 5:00 p.m. Roseau, Dominica.

Winding down after a day of teaching preparation I scrolled my social media timeline to find posts from friends in Dominica warning their neighbors that island was on hurricane watch. I sent texts to family and friends to see how their preparations were going. My cousin Sarah, a mother of two and English teacher at a Roseau girl's school, had been told to stay home (like all public-sector workers). She had been glancing at her laptop between childcare, chores and her own class preparations, tracking the hurricane, which had been named Maria. A name so ambivalently ominous: Maria/Mary invokes the mother of Christ the savior, yet, its onomastic origins lie with the old testament’s Miryam, sister of Moses, whose name signifies a "sea of bitterness,” “water,” “rebellion,” “elevation” or "hope.”1 This storm called Maria appeared to be gathering force on her approach from the Atlantic.

Louretta, a friend and shop assistant, was also at home. All employees of the pharmacy in Roseau (Dominica's capital) where she works were instructed to leave just two hours into their shift, allowing time for those from rural areas to get back before Maria made landfall. So, Louretta walked the short distance home, detouring via a supermarket in the heavy Roseau rain to buy some snacks for the night ahead. She reached the store to discover it packed with shoppers. One of just six main supermarkets on the island, people from all areas were frantically stocking-up on dry goods, bottled water, batteries and candles. "You know what, I’ll come back tomorrow,” she told herself. “Because,” she later elaborated, "honestly I did not think it would not have a tomorrow."

Receiving replies to my messages and scrolling further I learned that Maria was growing. Between lunchtime and 5:00 p.m. (Dominican time), Sarah watched it swell from a Category 2 to a Category 5 storm. ${ }^{2}$ She recalls, 
This fear, this panic just descended on me. When I told mommy_-I didn’t want to tell mommy-[but] when I told her, she just... she just sat down and she started to pray. 'Cause we knew a five is bad. We were not ready for a five. There was a type of uncertainty as to what was coming.

Recent experience recalls the fatal flooding and landslides of tropical storm Erika, which caused thirteen deaths in 2015, destroying eight hundred homes and causing damages valued at an estimated US\$483 million. ${ }^{3}$ However, despite its heavy rains Erika was not a hurricane, let alone a Category 5 one, the likes of which Dominica had not witnessed since memory-etched David in 1979. Every elder has a story of hurricane David, which struck a year after independence, taking thirty-seven souls, destroying seventy-five percent of the island's houses and decimating its agricultural sector (Honychurch 1995, 270-3). Auntie (Sarah’s mum; my mother's sister) bears vivid memories of David. Like Sarah she too was the mother of small children at the time and saw her verdant isle razed by violent winds. She watched David destroy everything in its path; waited in line for food aid immediately after the storm; and in the following months gradually rebuilt their damaged home. So, with memories of David and Erika in mind, at 6:00 p.m. when radio callers from Dominica's east coast reported winds that were ripping up roofing sheets, Sarah and her mother braced themselves for the worst. They waited with Sarah’s father, niece and two daughters in their small bayside home, next to an unnervingly calm Caribbean Sea. 


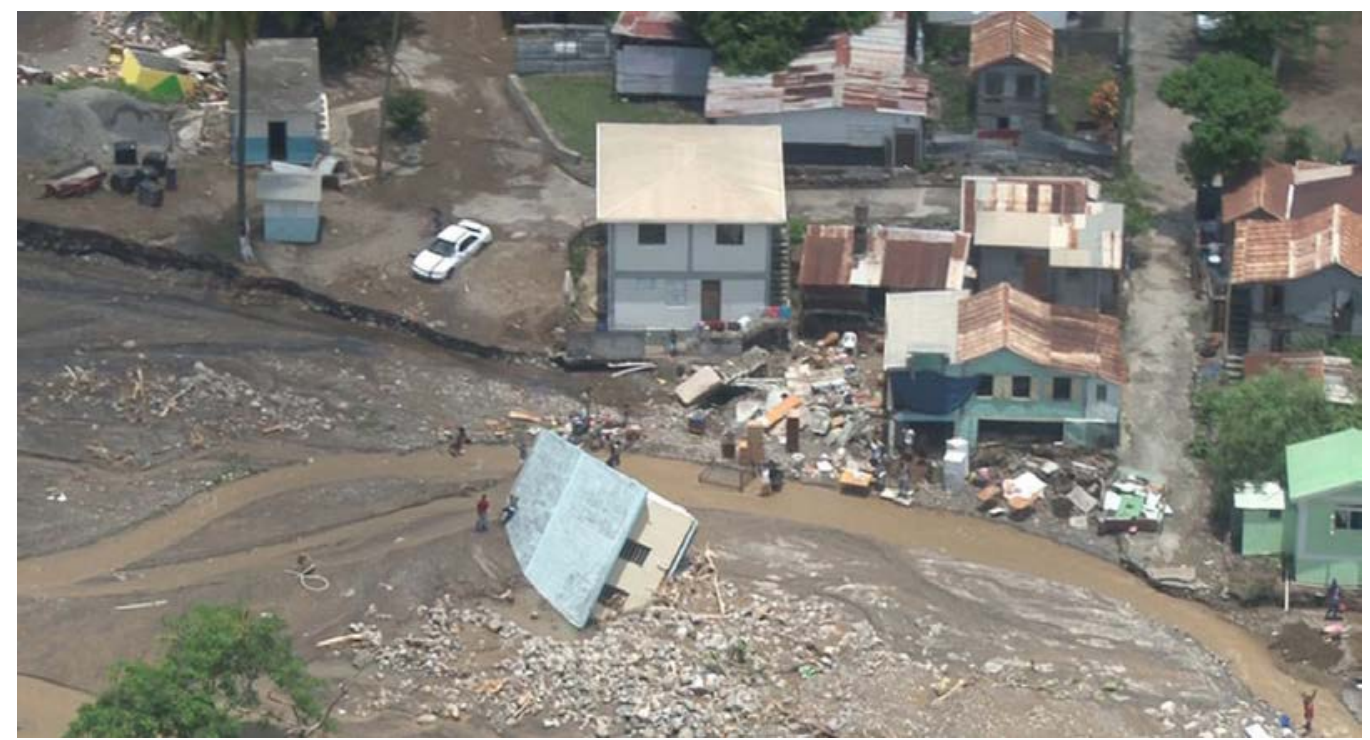

Figure 1. The aftermath of TS Erika. Colihaut, 2015.

From Dominican prime minister Roosevelt Skerrit's Official Flickr ${ }^{4}$

Louretta, living across town in a two-story house with her aunt and cousin, recalls the storm first hitting their home at around 7:00 p.m. With boarded windows and doors, she could not see much, but could hear and feel a force raging outside_- “It was howling... [and] every time the wind hit the house, it shook. It was like an earthquake.” Notwithstanding the havoc unfolding beyond her walls, Louretta somehow fell asleep after smoking an evening joint—until she was jolted awake when water started streaming through the jalousie shutters and beneath the door. Louretta, her aunt and cousin frantically mopped and wrung the water down the sink to keep the flooding at bay.

Similarly, Sarah had not long put her daughters to bed when, “all we heard was this screaming, this screaming sound. This wind that was just not stopping.” She thought it odd that she could not hear the sea, the thunder, or the rain as with any other storm-just the wind's howling. She would tell me later that, "People say the storm was talking to them: 'this woman was talking to me and she was screaming at me,"” they said on the radio and in the market. Sarah would hear elders describe Maria’s voice as that of a malevolent spirit, “a demon," "a monster." 5 Then 160 mph winds and debris slammed against the house, tearing 
off part of the roof and water poured in. Sarah directed her daughters (ages nine and five) to shelter under the dinner table whilst she and her mother mopped and prayed. She told me later, "there were times mommy and I were just praying out loud. We were shouting to god: 'What is this?'; 'What is happening?'” At about 7:30 p.m., the electricity went out. By 8:30 p.m. telecommunications were down and eventually Dominica lost contact with the outside world. The last messages were sent by the Prime Minister, Roosevelt Skerrit, via satellite phone at around 10:00 p.m. ${ }^{6}$ Then silence.

In the days that followed, the international news media scrambled for information, reconnaissance helicopters mapped the destruction (surveying over ninety percent of buildings as damaged) and a host of international donors pledged humanitarian aid and assistance with rebuilding. ${ }^{7}$ Globally dispersed Dominicans and their friends used social media platforms to try and locate loved ones. Online posts asked for updates on family members throughout the island, with comments conveying the embodied agony of not knowing if kin were alive or gone-_my heart is sick," "my chest hurting," they wrote. A week went by before contact; longer for those in Dominica’s far north, east or rugged interior (many of whom walked for hours to larger villages or "town" for food and phone charge to contact loved ones overseas). Eventually family members were reached and deaths announced—-thirty-one confirmed; thirty-four bodies still missing. Remittances were sent, outbound tickets booked and the long path of clearing and (re)building began. During this time of indeterminate existence--between chaos and normalcy, living on basic rations, without electricity, running water, clear roads or intact roofs to protect from persistent rains—-my regular checks on friends’ welfare brought a common response: “things bad, but we have life.” 
Harvey, Jose, Irma, Maria and Nate. Such innocuous sounding names. Yet, for residents of the region they speak a brutally "hyperactive” hurricane season. ${ }^{8}$ For Barbudans, Puerto Ricans and Dominicans, 2017 is arguably the most devastating storm season in living memory. The destruction of these storms continues to be felt by those left traumatized, who lost loved ones, who still lack basic amenities, remain homeless, cannot return to work and those taking refuge in other lands. And as the global climate warms, such ferocious seasons seem only set to intensify (Sealey-Huggins 2017).

Five days after Maria, Dominica’s prime minister stood shaken but steadfast before the UN general assembly. He spoke unequivocally of the dread visited upon his small island, reminding the world of its anthropogenic causes and imploring fellow leaders to respond, I come to you straight from the front line of the war on climate change. Warmer air and sea temperatures have permanently altered the climate between the tropics of Cancer and Capricorn. Heat is the fuel that takes ordinary storms—storms we could normally master in our sleep—and supercharges them into a devastating force... To deny climate change is to deny a truth we have just lived... We as a country and as a region did not start this war against nature! We did not provoke it! The war has come to us. ${ }^{9}$ 


\section{Introduction}

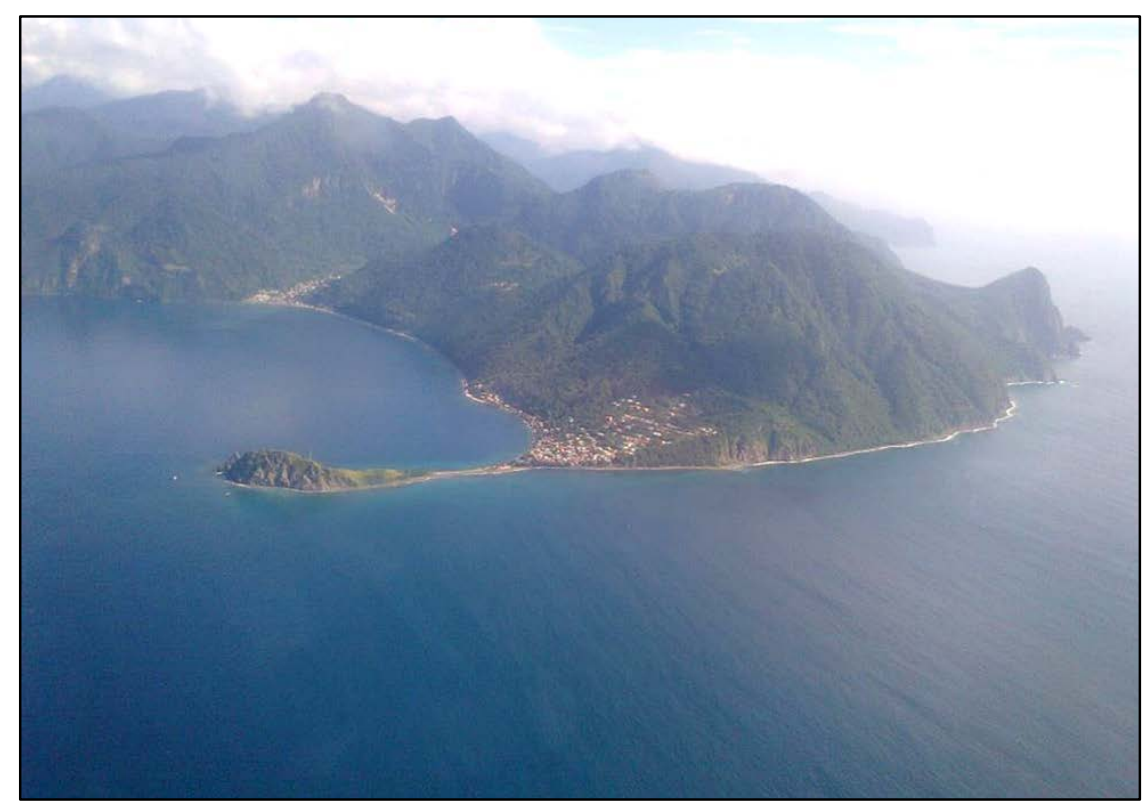

Figure 2. Before Maria: Aerial Photo of Dominica's South West. Photograph by author. 2014.

Who can forget those moments when something that seems inanimate turns out to be vitally, dangerously alive?

Amitav Ghosh (2016, 3)

Since Kalinago (“Caribs”) first named her Waiti’kubuli (“tall is her body”),

Dominicans have known their cloudy skies, volcanic mountains, “365 rivers,” fertile soils, Atlantic Ocean and Caribbean Sea to possess great animate potential (Honychurch 1995, xi). ${ }^{10}$ At no time is this more apparent than during a hurricane. Hurricanes present a frenzied nexus of overlapping agencies_-competing and coalescing forces that oscillate human worlds between order and chaos. They bring the supernatural, natural and human into frantic relation. In this paper, I suggest that we understand hurricane Maria—and any other 
hurricane-as my cousin and friend have in the preceding passage. Not as an abstract or asocial geological phenomenon, but as a complex set of relationships.

The opening of this paper told a story of Maria by outlining some of the relationships that constituted the hurricane. It detailed the relational narratives of those who lived through it, as well as utilizing my own relations to Dominica as a means of understanding Maria. We witness human relations with divine or malign forces: Papa Bonjay (God), who brings storms ("acts of god") and is implored to mercifully assuage their might. We also hear of "demons" and "monsters" who unleash their fury on the island, only to be rebuked with prayer. There are human relations with natural elements: wind that rips apart houses, tears down power lines and causes surging seas; rain that causes lethal landslides and turns rivers into raging torrents that bring down trees and entire buildings. Humans track, interpret and respond to these natural elements; they build on and shape their landscapes, both creating and attempting to mitigate such “natural risks.” And finally, there are social relations between humans who care for, protect, exclude and warn one another in the face of storms; humans who prepare for, suffer together, endure alone, or lose relatives during hurricanes; and who survive by building back their lives in the wake of deadly storms, whether collectively and independently, whether at home or in ecological exile; and humans who, at a global level, become a geological force-through mass deforestation, fossil fuel emissions and food production, altering the world's climate in irreversible ways. ${ }^{11}$ Each of these relations made Maria. Equally, such relations enable Dominicans to comprehend the profound power of a hurricane, its complex ramifications and how to survive it. 


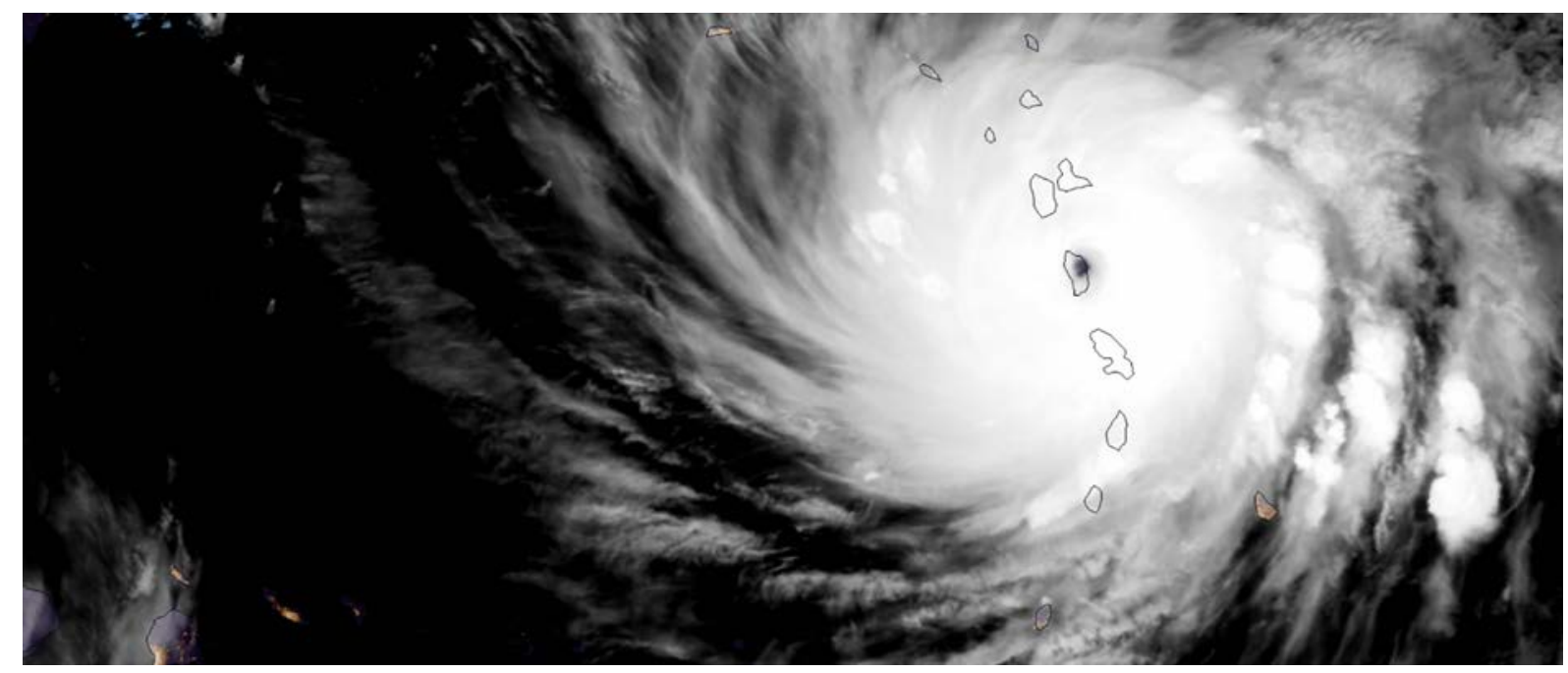

Figure 3. In the eye of the storm: Maria strikes Dominica. Image NOAA, 2017. ${ }^{12}$

Find the storm's swirling core, and understand.

Derek Walcott, The Tempest (in Deckard 2016, 25).

In this paper, I take the “core” of the social—kinship relations, personal networks and everyday modes of sociality_ as a route to understanding how Caribbean people make sense of, and live on, after deadly storms. I explore the role of the social in the narratives of three Dominicans who survive alongside and with the support of kin/friends_-both during hurricanes and thereafter. In the first ethnographic example, I describe how a middle-aged librarian reflects on memories of sudden familial cooperation and togetherness amidst the chaos of Hurricane David. Second, Louretta’s journey of dislocation: her extended family enable her to escape the hardship of post-Maria Dominica, until she finds herself adrift in East London with only distant kin. Finally, Sarah’s story of leaving Dominica: the sudden acceptance of her and her children’s long-awaited "green card” application to join her husband in America — after four years of waiting. But, Sarah is forced to leave behind her mother, father and siblings as they try to reassemble their lives at home. Across each of these narratives questions of "resilience"—a contemporary buzzword in disaster management discourse-emerge. However, rather than see resilience as a personality trait or quality that 
populations either possess, lack or may be trained into, I view resilience ethnographically. Hence, resilience emerges as something that is ever incomplete, temporally contingent and riddled with ambivalences. It resides in the social relations, lived practices and the shared ways of being that create community and serve as a resource during and after trauma. Therefore, I ask: What might resilience mean when refracted through Caribbean relational networks? How have Dominicans endured such shocks by relying on kinship, friendships and sociality? And finally, how can the close-grained ethnographic analysis offered here contribute a micro-social perspective to the emerging sub-field of Caribbean disaster scholarship (Ensor 2009; Katz 2014, Pérez 2001; Schuller 2016; Schwartz 2015; SealeyHuggins 2017)?

Methodologically, it seems apt to follow storms through the relations that connect me to Dominica. Elsewhere I have termed my methodology an "ethnography of relation” (Philogene Heron 2017), inspired by Glissant’s cosmopolitics and cultural poetics of "relation" — his theory of a world in social, political, economic and ecological contact, and of the Caribbean as a cultural space in a state of play between difference and unity (Britton 2012; Glissant 1992; 1997; Kullberg 2013, 77). ${ }^{13}$ Here I propose, an approach to ethnography that is not predicated on objectively knowing “The Other,” but an intuitive research praxis that is embedded in a wider process of evolving mutual understanding and participation, of which ethnographic documentation is just part—alongside friendship, kinship, voluntary service and extended human interaction (Philogene Heron 2017, 29).

This is an anthropology of connections - an involved ethnographic stance that seeks to overcome the reified difference implied by anthropology’s “savage slot” (Trouillot 2003) and strives for conversations between difference. Herein, I do not speak of "the field" as a 
bounded territorial site, an elsewhere that I can enter or depart, but follow diasporic "fields of relations” (Olwig 2007, 23) from Britain—where I was born, where my Dominican ancestors settled in the 1950s as members of the "Windrush generation," and where I now teach; to Dominica, where much of my maternal kin reside and where I undertook eighteen months of doctoral fieldwork on fatherhood between 2012 and 2014 (Philogene Heron 2017). The narratives that feature here emerge from conversations and interviews that began during fieldwork and are ongoing — through Erika and Maria, through less traumatic life events (births, birthdays and Christmases), as well as more quotidian interactions. As a young male in my mid-twenties, I became an everyday presence in my aunt’s home (just south of Roseau), developing close relationships with her husband, my cousins and their children; and with extended family living in the fishing village of Colihaut, further north on the west coast (where my deceased grandfather lived); as well as with cousins in the Roseau Valley (inland of the capital). Furthermore, I developed friendships and working relations with many men/fathers in the village where I resided, just south of my aunt's house. Here, I undertook most of my fieldwork and coached football. Returning to Dominica six months post-Maria was my first time visiting to the island in four years. In the interim, I had posted "barrels" of personal effects and relief (before and after Ericka and Maria), received packages of Dominican treats (Christmas cake, cocoa sticks and local spices), and endeavored to keep in regular contact with friends and family. ${ }^{14}$ But I now had a PhD, was aged thirty, married, worked in a university and was expecting a child. Life had changed radically, and this was visible through social media. I was different from the precocious chabin (“red skin”) nephew/fieldworker who "come out Englan to do a research" and "make his self” (found home in) Dominica as if he would live there forever. I was now a visitor in an altered place. I returned to be reunited with fathers, family and friends; to try to reconcile the absence of five neighbors (including two good friends) who died during the storm; as well as see that most 
who survived had either emigrated or lost considerable weight—from stress, food scarcity, clearing debris, collecting water and hand washing clothes. All this truly brought home the residual exhaustion and trauma that Maria left in her wake. I was to reencounter a familiar island and familiar people; though both had changed forever. Where possible, telephone calls, video chats, text messages and social media interactions sustained contact with kin, friends and research interlocutors between the time of my departure and return. Together with faceto-face open-ended interviews in England and Dominica, these interactions provide the empirical basis for the arguments made in this essay. Furthermore, I consulted various bodies of literature, including disaster response reports and Dominican and international news platforms, so as to provide a wide discursive context in which to situate my interlocutor's voices and my own.

\section{Orientations: Dominica, the Storm and After}

Dominica is an island of approximately seventy-one thousand souls that has (since Spanish contact in the fifteenth century) existed in a shifting state of relation with the world. ${ }^{15}$ The island stands at the cusp of the Anglophone-Francophone Antilles, owing to its history as an imperial pawn that wrested numerous times between French and British control, as indigenous Kalinagos, captive Afro-creoles, free persons of color and neg mawons negotiated diverging loyalties. When the British seized lasting control from the early nineteenth century to independence (1978), French missionaries, white and brown creole yeomen, and their enslaved laborers, had already cemented their influence throughout the island: English became the language of governance, hierarchy and education; kwéyol the language of Black and kalinago, peasant and laborer, informality and humor. With Mat'nik (Martinique) just fifty-eight nautical miles south and “Gwada” (Guadeloupe) sixty nautical miles north, a vibrant huckster trade, kin networks and a Dominican diaspora extended to 
these neighboring isles (and to Francophone St. Lucia and later St. Martin too). ${ }^{16}$ Moreover, Dominica now stands in enduring relation to three other areas where her diaspora has settled: the Anglophone Antilles (Antigua, St. Kitts, St. Vincent, Jamaica, Barbados, Trinidad, Anguilla and the Virgin Islands in particular); post-war Britain (beginning en mass with the 1950s “Windrush generation”); and North America (the US and Canada throughout the twentieth century to the present, as residents and for seasonal work). Dominican familial and friendship networks extend across these dispersed relational fields, ushering the movement of material goods (commercial; personal "barrels”/parcels), money (investments; cash transfers) and information (logistical; personal). Indeed, such relations have given Dominica, a small and seemingly “peripheral” island in the eastern Caribbean, a planetary reach (Baker 1994).

Dominica’s steep topography and dense vegetation have also informed this tendency to move and the economic conditions there. Dominica's ruggedly recalcitrant landscape limited the development of large plantations during the colonial period (Green 1999), resulting in a monocrop export economy that cycled through the boom and bust of various commodities such as sugar, cocoa, coffee, citrus and bananas (Trouillot 1988; Baker 1994). During the post-emancipation period, both citrus fruits and bananas brought stable revenues to the island. Yet, such external effects as those of US prohibition laws on northward lime exports in the 1920s (alongside the global effects of the great depression) or WTO rulings in the 1990s that eliminated guaranteed European markets for Caribbean bananas caused economic crises in Dominica. Externally driven downturns had devastating effects on Dominica's monocrop export economy and the wellbeing of its people. Crises like these, alongside several hurricanes and the everyday economic vagaries of post-slavery island life (underemployment and low wages), caused many throughout the twentieth century to emigrate in search of better opportunities. After the demise of the banana economy, economic life in the twenty-first century continues to be marked by a scarcity of cash incomes, 
particularly for the quarter of the population whose livelihoods center on agricultural smallholdings; as well as those who work in the small fishing, ecotourism, manufacturing (pepper sauces, teas, soaps) and informal trading (huckstering, higgling) sectors, whose incomes remain modest and variable (against a relatively high cost of living).

Given such precarity, Hurricane Maria served only to increase the economic challenges faced by Dominicans. A government report two months after the storm estimated that island wide losses/damages were valued at EC 3.54 billion (US\$ 1.3 billion), which was more than $226 \%$ of GDP. ${ }^{17}$ In livelihood terms, the near total destruction of backyard gardens and smallholdings, the deaths of most livestock and the destruction of approximately $40 \%$ of local fishing boats/equipment, cumulatively triggered a food crisis for almost half of the island's residents—-those who already lived "hand to mout" and could not afford to stockpile dry foods for the hurricane season. A most telling symbol of this food crisis was the conspicuous absence of "green fig" (green banana), a ubiquitous staple that, since the banana boom, had become a means of sustaining the island's families in times of scarcity (e.g. during banana price declines; see Trouillot 1988). Even six months after the storm, I would hear Dominicans lamenting the lack of "fig" on their plates, and during my last week on the island, I recall an aunt's excited description of a man striding through the Roseau market proudly holding a stem of green bananas on his head; "carrying that like a trophy, wii!”

However, immediately after Maria, many food stores, fishermen and market higglers either went out of business or emigrated. And for the shopkeepers who remained open increased overheads of petrol generators and import costs, combined with peaking demand and low supply, caused food prices to soar. (Although I witnessed many working-class Dominicans attributing these increases not to market forces but to greed and spite on the part of opportunistic entrepreneurs who were seen to be profiting from the island's misery.) Homes were also severely affected: by flooding, destroyed roofs and severe structural 
damage. Some $15 \%$ of all dwellings were recorded as "totally destroyed," $40 \%$ "severely damaged,” 20\% “moderately damaged,” 15\% “slightly damaged,” and just 10\% were recorded as having "suffered no damage” at all. ${ }^{18}$ Much of the island was without power for months and those who could access petrol generators relied on them for a few hours of electricity per night. Six months after the storm, at least a quarter of houses were still under blue tarpaulin or temporarily patched, and less than half of the island had been reconnected to the national power grid. All told, Dominica, which stood in an unequal state of relation to the wider world before the storm, was very much still reeling from the Hurricane half a year after her eye had passed. Considering this, the onomatology of Maria as a "sea of sorrow" reads as ever more apt. And yet, the contrasting connotation of "hope" still sits alongside it if we reconsider resilience within a Caribbean micro-social frame.

\section{Complicating Caribbean "Resilience" in the Age of the "Anthropocene"}

In 2017, the Antilles felt a kind of chaos from which many in the region are still reeling. It was a new yet familiar kind of chaos. ${ }^{19}$ The region had felt ecological, geological and human shocks many times before. ${ }^{20}$ But this hurricane season signaled a climatic ferocity of increased proportions. It presented the region with the reality of climate change-as an “existential threat” (Sealey-Huggins 2017) to small island states and citizens that stand in the firing line of ever more powerful and erratic weather systems. ${ }^{21}$ In the earth sciences, social sciences and humanities this moment has been termed "the Anthropocene.”22 That is,

A geological era of humanity’s own making... the Anthropocene signals a geological interval since the industrial revolution, where, through its activities, through its numbers, the human species has emerged as a geological force now altering the planet’s biosphere. Because of these developments the relatively benign planetary conditions of the Holocene- the previous 12,000 years, which enabled the 
establishment of agriculture and the rise of urban civilizations_-are in the process of transformation. $^{23}$

Whilst this term gives recognition to the human as a powerful geological agent, the incorporation Moore’s notion of "capitalist world-ecology” critically repositions this definition for it reminds us of the imperial political economy of the anthropocene (2003, 323; Sealey-Huggins 2017). European industrial revolutions and a world economic system governed by a shift from mercantilist to free market logics first began with imperial expansion, and, as Sydney Mintz reminds us (1986), with Caribbean plantations —an early site of chaos. ${ }^{24}$ Caribbean sugar produced by enslaved Caribbeans supported the take-off of early European industry via reinvested profits. It piloted pioneering agri-industrial methods (a rational modern "field-factory”), and of course, the sugar itself offered quick calories that quelled the hunger of an emerging European proletariat (Mintz 1986). So, in a sense, the capitalist source of the anthropocene was set in motion by eighteenth-century imperial extraction, in large part, from the Caribbean. And in return, today the anthropocene bares its brunt on the region; a region economically weakened by post-independence and neo-imperial politico-economic relations (Sealey-Huggins 2017). ${ }^{25}$ Given these repeating intervals of radical transformation that echo from plantation to the present (including via externally generated boom and bust export cycles outlined above), I am compelled to ask: How have Caribbean peoples come to navigate and mitigate such uncertainty in everyday terms? The answer, I suggest, can be located in particular Caribbean social resiliencies.

Since the turn of the twenty-first century, the "resilience" trope has come to dominate disaster mitigation, policy and scholarship (Barrios 2016, 29; Izdebski, Mordechai and White 2018). In the months after Maria, the government announced its plans to make "Dominica the first climate resilient nation in the world"-a commitment commended by such visiting dignitaries as the UN Secretary General, Prince Charles and Bill Clinton. ${ }^{26}$ Similarly, the 
notion of Dominica "building back better” has circulated widely, with development practitioners proposing that hurricane resistant building regulations, transport systems, power grids, food production and sea and river defenses be established to ensure the island can weather future storms. ${ }^{27}$ Herein the government has established an inter-ministerial agency to take up these challenges. ${ }^{28}$ Although, at the time of my visit in March-April 2018, it was uncertain how its activities would be funded and what it might realistically achieve in advance of the oncoming hurricane season. Throughout these high-level discussions uncritical references to "resilience” and "building back better” recurred, suggesting technical depoliticizing fixes to complex questions (e.g. the rehousing of displaced people) and presenting universalist expert notions of what "better” or "resilient” might mean. (Of course, these trends are by no means unique to Dominica or the Caribbean; see Barrios 2016; SealeyHuggins 2017). Herein, resilience was often conceived in top-down and binary (resilience vs. vulnerability) terms, as something a community possesses or lacks rather than a process. Notwithstanding the reality that large rebuilding projects demand structural oversight and acknowledging the limited resources of the Dominican state and civil society, maybe another pragmatic place to begin a conversation on resilience is from the ground-up - that is, starting with a ground level framing of how people are actively adapting to post-hurricane life by using the resources and networks within their grasp.

Such a perspective can contribute to the burgeoning body of Caribbean disaster scholarship, which tends to focus on large scale systemic and historical studies (e.g. of postearthquake Haiti: Katz 2014, Schuller 2016; or trans-Caribbean hurricanes: Pérez 2001; Ensor 2009; Schwartz 2015), by providing ethnographically rich analyses of practical familial responses and shared processes of meaning-making in the face of chaotic events. The goal here is to give a sense of and theorize how disaster survivors bring order to radically uncertain worlds. Kat Browne’s Standing in the Need (2015), an ethnography of an African 
American family’s gradual recovery from Hurricane Katrina, offers a stellar example of this. Her book reveals how post-storm life was navigated by an extended Louisiana kin network, for whom comforts like home-cooked food, gatherings and "bayou speak,” as well as cooperation in securing housing and engaging with state bureaucracy, offered a social buttress against their displacement. Sherrieb, Norris and Galea describe resilience as "the qualities or characteristics that allow a community to survive or even thrive following a collective trauma” (2010, 228), whilst Panter-Brick adds that “what matters to resilience is a sense of hope that life does indeed make sense, despite chaos, brutality, stress, worry, or despair" (Southwick et al. 2014, 6) Therefore, to synthesize these definitions with Browne’s ethnography is to gain a sense of how kinship, and social relations more broadly, can act as a resource that brings hope to those who have faced a collective trauma. To go further, I suggest that not only social relations, but also a Creole cultural disposition towards sustaining, spontaneously generating and reviving social relations in the face of indeterminacy, should be considered a resource or "resilience" that supports Caribbean people through moments of trauma. Here, it must be noted that I am not providing a normative reading of such habituated resiliencies - that they should somehow stand in place of an organized therapeutic response, or take on "the social burden of resilience" (Izdebski, Mordechai and White 2018) for states or aid agencies. Rather, my goal here is to understand precisely how Dominicans have survived painful, life-altering disjunctures, typically in the absence of therapeutic interventions.

In his preface to The Sociology of Slavery, Orlando Patterson (1967) reflects on what Charles Carnegie has concisely called the "problem of the social” (personal correspondence, 2017). That is, the question of how plantation societies born of violence and sustained through brutal hierarchical relations (of color/race/ethnicity/class) and quotidian chaos (e.g. familial separation, murder, death and severe punishment) have been able to maintain a 
common social fabric (albeit a varied, sometimes frayed and ever changing one). Throughout the history of Caribbean anthropology, scholars have reckoned with similar questions at various scales: of enduring neighborly distrust (Cohen 1955), cultural plurality (M. G. Smith 1965) and ethno-racial difference (Hoetink 1967), exceptional violence (Thomas 2011), everyday social disjuncture (Wardle 2002) and accusations of "badmind” (Lewis 2015) or Obeah (Crosson 2015), which each appear to stand at odds with a sense of social solidarity (Mintz 1965). And at the same time, anthropologists have remarked extensively on the richness of male peer sociality (Brana-Shute 1979; Lieber 1976; Wilson 1969, 1973) and conviviality (Eriksen 1990; McClish 2016), as well as a common (“Matrifocal”) kinship system that cross-cuts the society (R. T. Smith 1988) featuring bonds of familial solidarity, across vast distances (Olwig 2007; Seller 2005; Chamberlain 2006) and creative patterns of pragmatic "kinning,” often against the odds (Gordon 1987; Mintz and Price [1976] 1992, 43; Wardle 2004). Here, I take such kinship and sociality as organizing principles that stand as a counterpoint to an environmentally exacerbated problem of the social. Kinship and sociality serve, in the narratives that follow, to enable relatives and friends to support one another both in terms of practically surviving hurricanes and comprehending a sense of the future amidst the rubble that surrounds their lives. And narratives are significant as the medium for such sense-making, for as Rapport reminds us,

Narratives may be understood as stories people tell about themselves and their worlds. The medium of their narrational telling may vary... but what is invariant is the characteristic of narratives to propagate a meaningful sequence across time and space. Narratives embody a perceived order, and in their telling they maintain this order despite seeming temporal, spatial, experiential disjunctures. In a world in motion, narratives provide. a place cognitively to reside and make sense, a place to continue to be $(2000,82)$. 
Therefore, telling one's story of survival affords the possibility of teasing coherence from chaos; redrawing a sense of place amidst displacement; and provides a method of orientation towards a hopeful future.

\section{Surviving Storms: Three Narratives}

\section{A Moment of Unity}

Sam was just twelve when Hurricane David struck Dominica. Thirty-five years on, we sat in the library where he works (and where I was researching family histories) and somehow entered a conversation about Hurricane David. He recalled the date and time of the storm in an instant. 12:00 p.m. on Monday, August 27th, 1979. He told me how David battered Dominica for six long hours. He recalled ferocious winds that dismembered wooden shacks, tore down electric cables and stole the lives of two of his neighbors. At the time Sam was living in a modest three-room house just north of Roseau with his parents and several siblings. His father was an "absent-present" father who dwelt in the home but had little to do with them; so, his mother raised the eight children almost single-handily, with meagre “maintenance” (material support) from her husband. Sam’s adult brother (in his twenties) lived at the back of the house with his girlfriend. However, Sam described this brother as a “wicked man,” who had not been on speaking terms with him or his mother for several months following a violent disagreement. That is, until David.

"David threw down de mango tree on the house. It knock down a wall in the yard... [and] tear off part of the roof," Sam vividly recalled. He remembered the brother and his girlfriend running from their damaged room, across the yard and into the mother's room, where Sam, his mum and their siblings were huddled. "All of us now was there, under the bed. And that's when we started talking." As the winds swirled and their mother uttered The 
Lord’s Prayer, the brother suggested making a break for it, running to higher ground to avoid a potential sea surge (their house was located on flat land, perilously close to the Caribbean Sea). "Now, when the eye hit us the place was calm,” Sam recalled. So, they ran. They headed up the hill, finding shelter in a local businessman's three-story home with others from their neighborhood. They rode out the storm there together, thankful that god had spared their lives. And in the aftermath of David, as the brother salvaged (and looted) materials to fix his part of the house, he also brought home sheets of galvinage and fixed his mother's roof too.

It is a truism that hurricanes reveal fault lines of difference and inequality. As Faas and Barrios remind us, "In these contexts, relations of unequal power are thrown into relief in a sort of revelatory crisis” (2015, 290). The effects of storms like David, Erika or Maria are felt far worse by those in informal wooden settlements, by those who lack insurance and whose ancestors had to build homes on steep landslide-prone estate margins or squatted Crown Lands on the sea’s edge, after emancipation (Honychurch 2001). Storms expose inequities between those who "doh have" and those who "have," whose sturdy and insured concrete homes perch high above sea level.

And yet, storms can also bring a temporary spirit of togetherness. They can suddenly disrupt the naturalized social distance between social classes. Working class villagers who might never otherwise enter the home of local businessman receive refuge there, as Sam's family did. Hurricanes may create a "liminal” atmosphere and a spontaneous sense of communitas amidst their chaos (Turner 1967). As Deckard argues, an egalitarian antistructure may emerge in which "carnivalesque conditions [are] opened up by storm-events... [and] ordinary mores and hierarchies are suspended” (2016, 25). After Maria, this point was 
echoed by Dominican citizen journalist "Mystelics" who commented that the storm brought all Dominicans_rich and poor — to bathe together in the river. ${ }^{29}$ He noted,

those kind of situation make you humble, it make you humble. Because everybody become one. You can’t say “oh, I have dis and dat. Oh I have electricity”-no you don’t! “Oh, I have water” —no you don’t! Everyone has to go river, wait for rain for you to go and bathe... That is the simplicity of human kind. I guess that's what nature teaches us, to become simple.

While such a spirit of unity suspends the stratified relations of the society at large, this also extends to more localized differences between kin. As Sam’s narrative shows, David's wrath brought divided kin into conversation, cooperation and brought acts of filial kindness from an otherwise antagonistic mother and son. Amidst chaos and suffering, family divisions were temporarily healed in the interest of a common purpose-survival. As Louretta (whose narrative follows) recalled after Maria, “Even if you were not really talking regularly... you had to put differences aside because everybody at that point was the same.” Similarly, cooperation during storms can create kinship-bonds where they did not previously exist. Louretta spoke of a friend who spent Maria alone under her bed. (Her mother stranded visiting family on the remote east coast). This friend became like Louretta's sister after they spent the week after the storm living, bathing and fetching water in the river, as well as improvising rationed meals together. "She was...she is my family," Louretta insisted, emphasizing how the close solidarity of their shared post-storm life transformed their friendship into kinship. 


\section{An Uprooted Life in Waiting}

Twenty-four-year-old Louretta, a friend from my time living in Dominica, described the days that followed Hurricane Maria as “a haze.” At 7:00 a.m. on the morning after the storm, she remembers removing their boarded front door and leaving the house,

when I went outside it's like the whole place was dark. There wasn't any leaves on any of the trees...It was scary at that point in time because all the trees, everybody's houses, all the galvanize, it just went. Vehicles were flipped over, poles were down... and when you reach town [central Roseau] it's like you see the full destruction because everything's on the road, vehicles are piled up on each other.

Louretta walked and surveyed the damage. She described a carnivalesque atmosphere as she met strangers on the road who relayed their experiences of the storm. It became a spontaneous gathering, “a lime” (Eriksen 1990; McClish 2016) ${ }^{30}$

we just stood by the road and somebody just gave us a bottle of alcohol [taken from one of the damaged stores]. They gave us some chips, some glasses and chaser-so basically, we had a little...a little get-together.

They temporarily tackled trauma with humor: one man sharing a mock mundane account of leaving his home that morning to go to town, only to find his vehicle in a river and casually opting to walk instead (playfully presenting his decision as a matter of choice; locating agency in irony). As their island lay in ruins, Louretta and her acquaintances seized a moment to laugh, a moment of release and freedom from the chaos that had enveloped their world. "A lot of those days after the hurricane was either laugh or cry,” she later reflected; concluding, "Because, if you don’t look at the positive it will destroy you.” 
However, as the days wore on post-storm life got harder. Louretta learned that an uncle of hers in Dominica's north east had died during the storm: "he was in a shanty house, not really structured and it's next to a river. He fell asleep and like the river took a whole bunch of houses including his own. They found him like a good three villages away from where he lived.” "I don’t think I cried during any of this, because it was still surreal,” she later reflected. The stench of bodies from a mass grave at the cemetery nearby her home became commonplace. And alongside this daily reminder of death, the arduous work of maintaining life continued. Louretta, her friend, aunt and cousin would collect several heavy pails of water each day from the sous (spring); they scaled a large hill to bathe in the river (“and then by the time we get back were almost dirty again”); they improvised meals from scant supplies; and they slept "three of us on a mattress on the floor" (the only bedding not destroyed by water). "We were just going through the motions of what our motions now became,” she concluded, the tautological phrasing of her description mirroring the circularity of the moment. As she summed it up: "We [were] existing, but not living."

Ten days after the storm, Louretta’s mother sent her and her two younger siblings (who live in the countryside) ferry tickets for Guadeloupe. Her mother, a teacher who usually lives in Anguilla, had been staying in "Gwada” with a close friend-who Louretta knows as “auntie”- after Anguilla was ravaged by Hurricane Irma. Guadeloupe was offering onemonth visas for Dominicans (many of whom have friends/family there) to enable them to leave Dominica whilst they get back to their feet. Louretta recalls,

At that time, we don't really have time to think, we just know that we can't continue to live like this. You have nothing, you don’t know how to live with no water, no light [electricity], you can’t bathe. You just wanna leave... It was like. “who buys me the first ticket, that's where I go.” 
So, she left Dominica. But things were hard in "Gwada" too. Four extra bodies in her aunt's house placed pressure on already scant resources. Empathizing with her aunt's increased energy bills and the difficulty of accommodating them all, she reasoned, "those things take a toll because you always trying to make ends meet and you trying to be a good person but it's just like now there's more on your account."

Eventually, another of Louretta’s aunts, whom she had not seen in almost a decade, offered her a ticket to London. She stopped over with friends and family in Antigua for several enjoyable weeks, then flew on to London a month before Christmas 2017. I met up with her on a busy high street close to where she was staying in East London. Discussing her first impressions of the place, we joked about British fish and chips' lack of seasoning and London's bitter cold. These simple tropes, seasoning and climate, stood as powerful signifiers of the displacement she described as we sat in a café chatting. Adverse weather had brought her to London, but the lack of warmth of this giant (climatically and interpersonally cold) city simply reminded her of how far she was from home. And seasoning, which she remembers borrowing from neighbors (cive, garlic, onion, Maggi cubes) to collectively craft flavorsome makeshift meals after Maria, contrasted with the blandness of British food. "Seasoning is life,” she joked midway through our chat.

Food and familiar comforts have the potential to mitigate feelings of displacement (Bowne 2015). Louretta’s aunts and uncles had this in mind when they prepared Dominican meals (provisions, bakes, stewed red beans and callaloo) for her and asked her what she would like to eat on Christmas day. They even asked what she likes to do over the holidays and what she would like as a gift. Yet, this only served to remind her how far she was from those she would usually spend this season of familial togetherness with:

It's Christmas right now and I guess this is the time of being with your family or your loved ones.... The people I'm with here, they're somewhat family-like. Like, relations 
—blood—but they're not your loved ones... They're like “do you want anything?” and I’m like, “at this point I don’t expect any gifts. You're feeding me, you’re giving me a place to live. I don’t know what more I could possibly ask for”. So, it’s like it’s just to show how good-natured people are. 'Cause to them feeding you and giving you a place to live is nothing. But to you, it’s a big deal.

Louretta was grateful for the offer of a gift, of accommodating her food preferences and putting her up without asking for anything in return. She appreciated the kindness of aunts, uncles and cousins whom she had not seen for years, expressing such generosity towards her-especially as her six-month visa denied her from earning. Yet, there was certain personal burden that came with not being able to reciprocate their kindness and hospitality. ${ }^{31}$ This burden was exacerbated by her longing to be elsewhere. To be with family that were not only "blood," but whom she had grown with, knew intimately, and whom she gave to and received from without second thought.

“England is a great place,” Louretta asserted at one point, as if convincing herself to feel this statement to be true. "But...” she added, “it’s hard for me to say like, 'hey I’m on vacation,’ when all my friends back home, they don’t have electricity, water, internet.” Unable to contact close friends as routinely as she was used to and rarely venturing alone beyond her local area, I had the sense that Louretta felt isolated and uprooted in England; temporally inert, waiting for life to resume when she could return to a sense of place and familiar relationships. So, whilst she had been supported by an extended kin network to leave the hardship of post-Maria Dominica — for which she was clearly grateful—here, feelings of dependency on distant kin and her distance from familiar places and loved ones compounded her feelings of displacement. Adrift in East London, unable to work or to move freely in unfamiliar surroundings, she longed to return to her Caribbean. 


\section{Bittersweet Beginnings}

Auntie wept when Sarah finally announced that she and the children would be leaving for Florida. She would miss the lively presence of her grandchildren in their home. And whilst she knew this was a good opportunity for Sarah's young family, she found the departures of loved ones difficult (ever since grandma boarded a ship bound for England in the 1950s, when auntie was a child). Sarah and the children’s "papers” had finally been processed, some four years after her husband Omar, a Cuban citizen, emigrated there by utilizing America’s (now repealed) “wet foot, dry foot” law-which granted Cubans who set foot on American soil permanent residency. Omar had left Dominica after years of trying, with much frustration, to secure gainful employment on the island (as a driver, tour guide and telecoms operative). He currently worked two jobs in America (at an airport check-in and Uber), regularly sending remittances and visiting his wife and daughters during vacations (which doubled as visa related visits to the US embassy in Barbados to process Sarah and the girls’ papers). Now, after years of waiting and amidst the flux that followed Maria, the American embassy wrote to Sarah to say that their residency application had been approved. They were moving to Orlando.

Sarah had not planned to leave right away. "My intention was to stay in Dominica as long as I could,” she told me, hoping to help her parents and siblings get back to some state of normalcy. Relatively speaking, the extended family had not fared too badly from Maria. Granted, their house was without running water, mains electricity and blue tarpaulin covered the roof for two months. But, unlike her colleagues and students who lost loved ones and entire homes, Sarah felt no need to depart immediately. In fact, “when I look at it,” she assessed, "What I feel is a sense of gratitude. Because, you know... I still feel that we came out ok. My family came out ok.” So, she hoped to wait until the time felt right to go. And truth be told, she also felt reservations about leaving her home, her parents, her siblings, her 
friends and her school during this moment of hardship. Days after the storm, she remembers picking up a parcel of supplies from a friend on the port, and with astonishment she watched crowds of Dominicans bustling to leave by ferry, and scores of British, American and Canadian citizens being evacuated by helicopter. "It was like a mass exodus," she recalled with some dismay. Sarah was sure she did not want to abandon her small island during its time of need: "There was this thing, you know, a lot of [Dominican] people would say... 'you all are just running away.'” Indeed, I recall a social media post some weeks after the storm reading, "All able-bodied men and women who have left the country instead of staying to help rebuild... Please DO NOT COME BACK!!!” Sarah did not want to be seen in this light. Each time she considered her departure she told herself: "I'm not running away. I am not running away!”

Nonetheless, "When I looked at the situation I just had to accept that [staying] wasn't going to happen... I spoke to Omar he told me, 'I'm getting you out of there as soon as possible.”” They had discussed the health of their younger daughter (aged five), whose asthma was being triggered by the dust that lined the streets following the storm. They discussed the lasting psychological effects on their elder daughter (aged nine), who now became quiet and withdrawn each time it rained. And they discussed the fact that they could help her parents and siblings more "from outside" — being three less mouths to feed and sending home dollars and barrels (of clothes, foods, toiletries) when Sarah started working. So, she recalls, "I had to try and look at the positive side of leaving.” They decided that Sarah and the children would fly out on November 17th, just two months after the storm.

I video called Sarah in mid-January 2018 to see how they were acclimatizing. She shared her story and described moving to America as "bittersweet." Sarah and the children were happy to be reunited with Omar, but she admitted that leaving home, particularly in the circumstances, had been difficult. At the time of our conversation the girls were enrolled in 
school and Sarah had passed an interview for an online English teaching job that would fit around childcare. They were all adapting to their new life. Nonetheless, of the girls she noted, “I think they’ve adjusted faster than I have.” For them, it was an easy sell: new friends, being nearby their beloved father, and living in the same city as Disneyland made relocating an adventure. But, when I asked Sarah what she most missed about Dominica, it became clear why adjusting was harder for her. "Just the ability to get up and go," she replied, as she described being able to spontaneously walk or catch a bus along the busy coastal road to town, passing familiar faces and landmarks without needing to take a taxi or wait for a lift from Omar, as was now the case. She added that she misses Dominica's landscape, watching the sun rise from behind the mountains above her family's bay side home and set onto the Caribbean Sea beneath it. As she spoke, Sarah seemed to echo Derek Walcott who once stated that “you can't wake up in the Caribbean without looking out of the window with a sense of astonishment in the renewal that you see.” 32 In fact, before she left her once green island, now scrubbed brown by Maria's winds, had begun to bring such a sense of renewal:

The plants around the house started growing first. The trees by the bay...those that were still standing, they started, the green leaves started sprouting. And it was, you know when new leaves start growing, it's this bright green. They tell you that green is the color of hope.

She told me that that her new housing complex has a man-made pond, manicured shrubbery and nice trees. In other words, "stuff that’s natural.” And yet, "I haven’t felt it yet, that this is home. I miss my mountains to be very honest. I miss my mountains.”

And finally, she missed the sociality of home: "just seeing people I know" she added, evoking the small and neighborly nature of her community. This lacking in Orlando, 
That Dominican feeling... having conversations with people that you'd never spoken to before. People here aren’t like that. You'll get a smile. I’ve gotten a few hellos and so on. But at the same time, you know that West Indian thing. West Indians are just, open and you know, hey communicate. And there's just a warmth. It's not here.

Wardle has described this West Indian "thing” as the product of Caribbean cosmopolitanism; as a "West Indian cultural openness" to humor and play, a vibrant capacity to accommodate difference, and in so doing craft community (2000; 2007). Sarah had studied in Cuba, where she and Omar met. There she found such openness, a feeling of community and home. But despite moving there because of its longstanding relationship to Cuba, Florida did not yet feel like home to Sarah. However, "this is gonna have to be home," she insisted, whether she felt it or not. She looked to the future with a sense of determination,

Definitely we're gonna be travelling back [to Dominica] to do whatever I can to help the family. But as far as settling down, this is it for us. We're just gonna make it the best way we can. If we have to work two jobs, we work two jobs. Whatever it is, we do what we have to.

Therefore, Sarah came to Florida with a steadfast optimism and desire to provide the best for her children. She pushed past her reservations about leaving Dominica’s familiarity and community, learning to bear her feelings of missing the Caribbean for the sake of her family at home and in Florida, her new home. Thus, Sarah’s story presents a mother/wife/daughter/sister navigating a chaotic present to locate familial security in an uncertain future.

\section{Improvising Resilience}

Across these three accounts, the social emerges as powerful means of dealing with and living through the trauma of a hurricane. Thus, social networks and the relations that 
constitute them afford certain resiliencies: resources with which people navigate and live through the trauma of sudden shocks. The social as resilience is activated in moments of conviviality and humor, in which people generate spontaneous episodes of togetherness and egalitarian solidarity amidst the chaotic aftermath of storms. The social as resilience is activated when personal differences between kin and class distance between neighbors are suspended, and solidarities form between those who navigate the hardship of post-storm life together. The social as resilience is activated when relatives send remittances and offer support to affected family members, enabling their emigration from devastated areas by buying tickets, opening their homes and feeding them in the weeks and months after a hurricane. Finally, the social as resilience brings parents to endure the relocation of their lives in the hope of securing a better present and future for their children.

In a broader sense, it is the historic, cultural and political relations between Dominica and the world that made such relocations possible. This relational poetics enables aunts/uncles who emigrated to Britain in the second half of the twentieth century to "send for” their niece, post-Maria. It enables networks of friendship and diplomatic ties that extend to Guadeloupe, making way for the accommodation of families seeking refuge. And it enables relations of love between a Dominican and Cuban, who eventually make use of antagonistic international relations between Cuba and America (who offer residence to Cuban emigrants) to take up residency in Florida. These wide-reaching fields of relations afforded various routes through which Dominican narrators could reinvigorate relationships, access support, locate new opportunities and travel to new pastures.

However, as these accounts also reveal, such social resilience is often incomplete, ambivalent and bittersweet. Social networks and relations can only do so much in response to hurricanes of the intensities that the Caribbean witnessed in 2017. The social debris of Maria, Irma and others is visible throughout the Caribbean world—homes wrecked, families 
scattered, loved ones lost. Indeed, convivial solidarities may give way to sobering hardship; journeys to safety may bring longings for home; and new beginnings may be riddled with uncertainty. Nonetheless, the social or to be more specific, family and friendships provide powerful motivators for weathering shocks - to protect relatives during storms (blood or otherwise) and to provide for, and emotionally support them thereafter. Furthermore, it must be noted that social resilience is not something that is formally inculcated or taught. Rather, these are patterns that emerged in everyday life in response to traumas and hardships that extend back to plantation histories of the island. These dispositions have enabled Caribbeans to navigate quotidian economic uncertainty, dramatic shocks and to eke out opportunities through improvisation in response to life's vagaries.

It is instructive to consider these narratives alongside Carnegie’s notion of "Strategic Flexibility” (1982), for here we gain sense of the dispositions or patterns of thought that underpin the social resilience I have discussed. "Strategic flexibility” is a subject's cultivation of and openness to multiple potential opportunities as an outcome of any given situation. That is, a responsiveness and ability to "move” on any social or economic opportunity that presents itself to the individual (see also Prentice 2015 and Rodman 1971). For example, Carnegie refers to an unemployed teenager who hopes to move to America one day. To do so, the young man lines up several trips to other Caribbean territories, with the awareness that any of those could enable him to work and save money, as well as meet the right people to facilitate his trip. Options ever open; subject poised to seize them. This orientation applies for relationships too. Caribbean subjects often sustain an open field of relations which can be leveraged and may offer support as and when it is needed. However, in cases of acute crisis an individual's options narrow and circumstances demand a quicker move. For example, Louretta stated that as life became harder in Dominica, "It was like, who buys me the first ticket, that's where I go.” The strategic decision takes on a greater urgency; "If you lose the 
dog grab the cat,” the St. Lucian saying goes (Carnegie 1982, 11). But, in the context of a hurricane: if you lose everything, seize the best option you can. And as Carnegie reminds us, the expansive social fields that Caribbean people create and inhabit (of near and distant networks) open possibilities to utilize such relations in times of need. Herein, when viewing the narratives that populate this paper through a strategic flexibility frame, we can discern how this social logic opens the way to complex patterns of social resilience.

In closing, we have here a complicated model of resilience that grows from an adaptive, improvisational and processual social ecology that is deeply embedded in Caribbean history and contemporary ways of being. Such resilience, as this essay has shown, may lift storm survivors from Maria’s “sea of sorrow” to a place of "hope.” Hope being, "not the conviction that something is going to turn up well, but the certainty that something makes sense, however things are going to turn out”' (Vaclac Havel in Southwick et al. 2014, 6). Put simply, a steadfast faith in the future. So, as the Antilles endure the forthcoming hurricane season, as well as infrastructure and housing, let us keep the social in mind as a central element that enables Caribbean peoples to survive storms.

\section{Acknowledgements}

Thank you to Sam, Louretta and Sarah for sharing your stories of David and Maria. Also, thank you to Goldsmiths College, University of London for funding the field research that informs this paper. 


\section{References Cited}

Anatol, Giselle. 2015. Things That Fly in the Night. New York: Rutgers University Press.

Baker, Patrick. 1994. Centring the Periphery: Chaos, Order, and the Ethnohistory of Dominica. London: McGill-Queen’s University Press.

Barrios, Roberto. 2016. "Resilience: A Commentary from the Vantage Point of Anthropology.” Annals of Anthropological Practice, 40(1): 28-38.

Benítez Rojo, Antonio. 1992. The Repeating Island. Translated by Maraniss, J. E. Durham: Duke University Press.

Blaser, Mario. 2016. “Is Another Cosmopolitics Possible?” Cultural Anthropology 31(4): 545-570.

Brana-Shute, Garry. 1979. On the Corner: Male Social Life in a Paramaribo Creole Neighborhood. Prospect Heights, IL: Waveland

Britton, Celia. 2012. “Ethnography as Relation: The Significance of the French Caribbean in the Ethnographic Writing of Michel Leiris.” French Studies 66(1): 41-53.

Browne, Katherine. 2015. Standing in the Need: Culture, Comfort, and Coming Home after Katrina. Austin: University of Texas Press.

Carnegie, Charles. 1982. "Strategic Flexibility in the West Indies: A Social Psychology of Caribbean Migration.” Caribbean Review 11(1): 10-13.

Chamberlain, Mary. 2006. Family Love in the Diaspora. London: Transaction.

Cohen, Yehudi. 1955. "Four Categories of Interpersonal Relation-Ships in the Family and Community in a Jamaican Village.” Anthropological Quarterly 28(4): 121-147. 
Crawford-Brown, Claudette and Melrose Rattray. 1994. The "Barrel Children" of the Caribbean: The Sociocultural Context of the Migrant Caribbean Family. Mona, Jamaica: Dept. of Sociology and Social Work, University of the West Indies.

Crosson, Brent. 2015. "What Obeah Does Do: Healing, Harm, and the Limits of Religion.” Journal of Africana Religions 3(2): 151-176.

Deckard, Sharae. 2016. “The Political Ecology of Storms in Caribbean Literature.” In The Caribbean: Aesthetics, World-Ecology, Politics, edited by Chris Campbell and Michael Niblett, 25-45. Liverpool: Liverpool University Press.

Douglas, Mary. 2002. “Foreword.” In The Gift: The Form and Reason for Exchange in Archaic Societies, Marcel Mauss, ix-xxi. London: Routledge.

Ensor, Marisa ed., 2009. The Legacy of Hurricane Mitch: Lessons from Post-Disaster Reconstruction in Honduras. Tucson: University of Arizona Press.

Eriksen, Thomas Hylland. 1990. "Liming in Trinidad: the art of doing nothing.” Folk 32(1): 23-43.

Faas, A. J., and Roberto Barrios. 2015. “Applied Anthropology of Risk, Hazards, and Disasters.” Human Organization 74(4): 287-295.

Ghosh, Amitav. 2016. The Great Derangement: Climate Change and the Unthinkable. Chicago: University of Chicago Press.

Glissant, Édouard. 1992. “Michel Leiris: The Repli and the Depli.” Translated by Cynthia Mesh. Yale French Studies 81: 21-27.

Glissant, Édouard. 1997. Poetics of Relation. Translated by Betty Wing. Ann Arbor: University of Michigan Press. 
Gordon, Sally. 1987. “I Go to 'Tanties’: The Economic Significance of Child-Shifting in Antigua, West Indies.” Journal of Comparative Family Studies 18(3): 427-443.

Green, Cecilia 1999. “A Recalcitrant Plantation Colony: Dominica, 1880-1946.” NWIG: New West Indian Guide 73(3/4): 43-71.

Hoetink, Harry. 1967. The Two Variants in Caribbean Race Relations: A Contribution to the Sociology of Segmented Societies (Vol. 2). London: Oxford UP.

Honychurch, Lennox. 1995. The Dominica story: A History of the Island. London: Macmillan.

Honychurch, Lennox. 2001. “Slave Valleys, Peasant Ridges: Topography, Colour and Land Settlement on Dominica.” Proceedings of the University of the West Indies Dominica Country Conference. Roseau, Dominica: University of the West Indies.

Izdebski, Adam, Lee Mordechai, and Sam White. 2018. "The Social Burden of Resilience: A Historical Perspective.” Human Ecology 46(3): 1-13.

Katz, Jonathan. 2014. The Big Truck That Went By: How the World Came to Save Haiti and Left Behind a Disaster. New York: St. Martin’s Press.

Kullberg, Christine. 2013. The Poetics of Ethnography in Martinican Narratives: Exploring the Self and the Environment. Charlottesville: University of Virginia Press.

Latour, Bruno. 2004. "Whose Cosmos, Which Cosmopolitics? Comments on the peace terms of Ulrich Beck.” Common Knowledge 10(3): 450-462.

Lewis, Jovan Scott. 2015. “A So Black People Stay: Bad-mind, Sufferation, and Discourses of Race and Unity in a Jamaican Craft Market.” The Journal of Latin American and Caribbean Anthropology 20(2): 327-342. 
Lieber, Michael. 1976. “'Liming’ and Other Concerns: The Style of Street Embedments in Port-Of-Spain, Trinidad.” Urban Anthropology 5 (4): 319-334.

Mantz, Jeffery. 2007. “Enchanting panics and Obeah anxieties: concealing and disclosing Eastern Caribbean witchcraft.” Anthropology and Humanism 32(1): 18-29.

McClish, Carmen L. 2016. “Good Liming in Trinidad: The Art of Doing Something.” Liminalities 12(4): 1.

Mintz, Sidney. 1965. “The Caribbean as a socio-cultural area.” Cahiers d'Histoire Mondiale/ Journal of World History/Cuadernos de Historia Mundial 9(4): 912-37

Mintz, Sidney. 1986. Sweetness and Power: The Place of Sugar in Modern History. London: Penguin.

Mintz, Sidney and Richard Price. [1976] 1992. The Birth of African-American Culture: An Anthropological Perspective. Boston: Beacon Press.

Moore, Jason W. 2003. “The Modern World-System as Environmental History? Ecology and the Rise of Capitalism.” Theory and Society 32(3), 307-377.

Olwig, Karen Fog. 2007. Caribbean Journeys: An Ethnography of Migration and Home in Three Family Networks. London: Duke University Press.

Patterson, Orlando. 1967. The Sociology of Slavery: An Analysis of the Origins, Development, and Structure of Negro Slave Society in Jamaica. London: Macgibbon \& Kee.

Pérez, Louis. 2001. Winds of Change: Hurricanes \& the Transformation of NineteenthCentury Cuba. Chapel Hill: University of North Carolina Press. 
Philogene Heron, Adom. (2017). “Fathermen: Predicaments in Fatherhood, Masculinity and the Kinship Lifecourse. Dominica, West Indies.” PhD diss., St Andrews: University of St Andrews Thesis Repository.

Prentice, Rebecca. 2015. Thiefing a Chance. Boulder: University Press of Colorado.

Rapport, N. 2000. “The Narrative as Fieldwork Technique: Processual Ethnography for a World in Motion.” In Constructing the Field: Ethnographic Fieldwork in the Contemporary World, edited by Vered Amit, 79-103. London: Routledge.

Rodman, Hyman. 1971. Lower-Class Families: The Culture of Poverty in Negro Trinidad. New York: Oxford University Press.

Schuller, Mark. 2016. Humanitarian Aftershocks in Haiti. New Brunswick: Rutgers University Press.

Schwartz, Stuart. 2015. Sea of Storms: A History of Hurricanes in the Greater Caribbean from Columbus to Katrina. Oxford: Princeton University Press.

Sealey-Huggins, Leon. 2017. “' $1.5^{\circ} \mathrm{C}$ to Stay Alive’: Climate Change, Imperialism and Justice for the Caribbean.” Third World Quarterly 38(11): 2444-2463.

Seller, Robbyn. 2005. “ “Out of state’ But Still in Mind: Family Love and the Cultural Context of Migration in Dominica, Eastern Caribbean.” Les Cahiers du Gres 5(1): 43-59.

Sherrieb, Kathleen, Fran Norris, and Sanrdo Galea. 2010. “Measuring Capacities for Community Resilience.” Social Indicators Research 99(2): 227-247.

Smith, Raymond T. 1988. Kinship and Class in the West Indies: A Genealogical Study of Jamaica and Guyana. London: Cambridge University Press. 
Smith, Michael Garfield. 1965. The Plural Society in the British West Indies. University of California Press.

Southwick, Steven, George Bonanno, Ann Masten, Catherine Panter-Brick, and Rachel Yehuda. 2014. “Resilience Definitions, Theory, and Challenges: Interdisciplinary Perspectives.” European Journal of Psychotraumatology 5(1): 25338.

Thomas, Deborah. 2011. Exceptional Violence: Embodied Citizenship in Transnational Jamaica. Durham, NC: Duke University Press.

Trouillot, Michel Rolph. 1988. Peasants and Capital: Dominica in the World Economy. London: Johns Hopkins University Press.

Trouillot, Michel Rolph. 2003. Global Transformations: Anthropology and the Modern World. New York: Palgrave Macmillan.

Turner, Victor. 1967 “Betwixt and Between: The Liminal Period in Rites de Passage.” In The Forest of Symbols: Aspects of Ndembu Ritual, 93-111. Itaca, NY: Cornell University Press.

Wardle, Huon. 2000. An Ethnography of Cosmopolitanism in Kingston, Jamaica. NY: Edwin Mellen.

Wardle, Huon. 2002. “Ambiguation, Disjuncture, Commitment: a Social Analysis of Caribbean Cultural Creativity.” Journal of the Royal Anthropological Institute 8(3): 493-508.

Wardle, Huon. 2004. “Choosing Parents: Adoption into a Global Network.” In CrossCultural Approaches to Adoption, edited by Fiona Bowie, 197-208. London: Routledge. 
Wardle, Huon. 2007. “A Groundwork for West Indian Cultural Openness.” Journal of the

Royal Anthropological Institute 13(3): 567-583.

Wilson, Peter. 1969. "Reputation and Respectability: A Suggestion for Caribbean

Ethnology.” MAN 4(1): 70-84.

Wilson, Peter.1973. Crab Antics: The Social Anthropology of English-Speaking Negro

Societies of The Caribbean. New Haven: Yale University Press.

Zalasiewicz, Jan, Colin N.Waters, Mark Williams, Anthony D.Barnosky, Alejandro Cearreta, Paul Crutzen, Erle Ellis et al. 2015. "When Did the Anthropocene Begin? A Mid-

Twentieth Century Boundary Level is Stratigraphically Optimal.” Quaternary

International 383: 196-203.

\footnotetext{
${ }^{1}$ Maas, Anthony. 1912. “The Name of Mary.” In The Catholic Encyclopedia. New York: Robert Appleton Company. New Advent website. Accessed November 1, 2017.

http://www.newadvent.org/cathen/15464a.htm

${ }^{2}$ Category 5 is the maximum rating on the Saffir-Simpson Scale (1-5), with wind speeds upwards of 157mph. According to the United States National Hurricane Center, in a Category 5 storm, "catastrophic damage will occur: A high percentage of [wood] framed homes will be destroyed, with total roof failure and wall collapse. Fallen trees and power poles will isolate residential areas. Power outages will last for weeks to possibly months. Most of the area will be uninhabitable for weeks or months.” For a detailed breakdown and graphic representation of a Category 5 storm, see "Saffir-Simpson Hurricane Wind Scale." National Hurricane Center website. Accessed November 1, 2017.

https://www.nhc.noaa.gov/aboutsshws.php

In Dominica, projections and outcomes are far more severe. Structures are built at lower cost and residential building codes are less stringent and more flexibly applied.

3 “Dominica: Lessons Learned from Tropical Storm Erika." Special Reports. ACAPS website, October 2017. Accessed November 1, 2017. https://www.acaps.org/special-report/dominica-lessons-learnedtropical-storm-erika

${ }^{4}$ Accessed January 11, 2018. https://www.flickr.com/photos/rooseveltskerrit/albums/72157655549907704

${ }^{5}$ Such descriptions of Maria were often gendered and described her in similar terms to how Dominicans speak of soukouyans, shape shifting witches (Mantz 2007; Anatol 2015). Many described how Maria's howls sounded like the voice of someone in distress, intended to lure individuals out of their homes (to investigate) and thus bring them into harm's way.

${ }^{6}$ Worley, Will. 2017. "Maria: Dominica PM gives terrifying account of being at 'complete mercy' of a Category 5 hurricane.” The Observer website, September 19. Accessed November 1, 2017.

https://www.independent.co.uk/news/world/americas/maria-latest-updates-dominica-prime-ministerrossevelt-skerrit-hurricane-category-5-account-a7954616.html.
}

${ }^{7}$ See the CARICOM-UN High Level Pledging Conference website for a breakdown of funds pledged. Accessed January 11, 2018. http://resilientcaribbean.caricom.org/wp-content/uploads/2017/12/Update-onPledges.docx

${ }^{8}$ According to Brian McNoldy (Senior Research Associate, University of Miami, School of Marine \& Atmospheric Science) the Accumulated Cyclonic Energy rating for the year's storms is categorised as 
"hyperactive,” measuring 229\% of the average annually. See: McNoldy, Brian. 2017. "Hurricane season usually winds down in November, but this hasn't been a normal season.” The Washington Post website, October 31. Accessed November 1, 2017. https://www.washingtonpost.com/news/capital-weathergang/wp/2017/10/31/hurricane-season-usually-winds-down-in-november-but-this-hasnt-been-a-normalseason/?utm_term=.f5c8a2ee11d9

9 "Prime Minister Roosevelt Skerrit of the Commonwealth of Dominica addresses the general debate." UNGA $72^{\text {nd }}$ Session. United Nations General Assembly (UNGA) website, September 23, 2017. Accessed November 1, 2017. https://gadebate.un.org/sites/default/files/gastatements/72/dm_en.pdf

${ }^{10}$ Local lore and ecotourism promotional materials describe Dominica- "the nature isle of the Caribbean"-as "the land of 365 rivers" (one for each day of the week). Yet, my parenthesis speaks to the contested nature of this figure.

${ }^{11}$ Of course, there are other relations such as those between humans and animals, but these lie beyond this immediate purview of this paper.

${ }^{12}$ National Oceanic and Atmospheric Administration (NOAA) satellite image of Hurricane Maria making landfall on September 18 ${ }^{\text {th }}$ 2017. See Thompson, Andrea. 2017. “'Don't Let Your Guard Down': Atlantic Hurricane Season Isn't Over Yet”. Livescience.com website. October 4. Accessed May 1, 2018.

https://www.livescience.com/60596-hurricane-lull-but-season-not-over.html

${ }^{13}$ Cosmopolitics is understood here as the fraught power dynamics of creating a shared world across bounds of difference (Blaser 2016; Latour 2004).

${ }^{14}$ Blue (plastic) and brown (cardboard) shipment barrels are ubiquitous across the Caribbean as vessels of remitted clothes, dry foodstuff, toiletries, small electronics and anything else emigrant kin and friends pack in them to send home. They constitute material holders of care from loved ones who intend to be "out of state, but still in mind" (Seller 2005). For perspectives on the barrel as signifier of Caribbean diasporic familial support, see Crawford-Brown and Rattray (1994) as well as:

Philogene Heron, Adom. 2017. "Barrel Necessities: Caribbean Stories of Love and Affection.” Talking

Humanities website, November 21. Accessed July 1,

2018. https://talkinghumanities.blogs.sas.ac.uk/2017/11/21/barrel-necessities-caribbean-stories-of-love-andaffection/

Jokhan, Mala. 2007. "Parental absence as a consequence of migration: Exploring its origins and perpetuation with special reference to Trinidad.” St. Augustine, Trinidad: Sir Arthur Lewis Institute of Social \& Economic Studies, University of the West Indies. Accessed July 1.

2017. https://sta.uwi.edu/conferences/salises/documents/Jokhan\%20M.pdf

${ }^{15}$ The 2011 census recorded the population to be 71,293. See: "2011 Population and Housing Census." The Government of Dominica website. Accessed May 1, 2018.

http://www.dominica.gov.dm/cms/files/2011_census_report.pdf

However, this is only a snapshot of a mobile population, many of whom "go and come" from the diaspora throughout an annual cycle. The figure is therefore subject to change. Estimates suggest this number is likely to have decreased significantly post-Maria, with some speculating (in the absence of verifiable statistics) that it may have dropped to as low as 45,000 with the high out-migration levels immediately after the storm. See: Jelly-Schapiro, J. and L. Honychurch. 2017. "Dominica: After the Storm.” New York Review of Books website, December 28. Accessed May 1, 2018.

http://www.nybooks.com/daily/2017/12/28/dominica-after-the-storm/

${ }^{16}$ The steep and densely forested terrain of the island meant that until a transinsular road was built in the 1950s, travel from northern and southernmost Dominica was easier by fishing boat to the neighbouring French isles than by track to the capital (in the south west).

17 The Government of Dominica. 2017 (November 15th). "Post-Disaster Needs Assessment.” reliefweb.int website. Accessed May, 1 2018. https://reliefweb.int/sites/reliefweb.int/files/resources/dominica-pdnamaria.pdf

${ }^{18}$ The Government of Dominica $(2017,13)$. See note 16 above.

${ }^{19}$ Many theorists of the Caribbean have turned to chaos theory as an organising metaphor for the patterns of order and disorder that repeat throughout the region (Benitez Rojo 1992).

${ }^{20}$ Ecological (e.g. hurricanes, landslides), geological (e.g. earthquakes, volcanoes) and human shocks (e.g. economic crises, political turmoil, enslavement and indigenous massacres).

${ }^{21}$ See also: Girvan, Norman. 2010. "Are Caribbean countries facing existential threats?” Caribbean 360 website. Accessed November 1, 2017.

http://www.caribbean360.com/opinion/are_caribbean_countries_facing_existential_threats 
22 There is considerable debate as to specifically when this moment began. See Zalasiewicz et al. 2015. However, the industrial revolution is taken as one start-mark.

${ }^{23}$ Dibley, Ben. 2012. “'The shape of things to come': Seven theses on the Anthropocene and attachment,” Australian Humanities Review (Ecological Humanities) 52. Accessed November 1, 2017.

http://www.australianhumanitiesreview.org/archive/Issue-May-2012/dibley

${ }^{24}$ These plantation societies were born of chaos (Benitez Rojo 1992): With European settlement came indigenous genocide; then developed stratified sites of production characterized by a racialized division of labor between European plantation owners/managers and drivers and kidnapped and transplanted West African laborers. These were regimes governed by spectacular violence and complex negotiations of consent that kept the societies from being torn asunder.

${ }^{25}$ Via unserviceable debt burdens, high FDI dependency/foreign ownership of national assets, bilateral aid dependency, "overseas territory" governance and externally dictated financial market vagaries.

See also: Beckles, Hilary. 2017. "Irma-Maria: A reparations requiem for Caribbean poverty,” The Jamaica Observer website, October 9. Accessed December 1, 2017. http://www.jamaicaobserver.com/history/irmamaria-a-reparations-requiem-for-caribbean-poverty_112666?profile=1096

26 “UN chief lauds Dominica's vision to become first climate-resilient nation after recent devastation.” United Nations website, October 9, 2017. Accessed November, 1, 2017.

http://www.un.org/sustainabledevelopment/blog/2017/10/un-chief-lauds-dominicas-vision-to-becomefirst-climate-resilient-nation-after-recent-devastation/

"Prince Charles hails 'resilience' of hurricane-battered Dominicans.” Dominica News Online website, November 20, 2017. Accessed March, 1, 2018.

http://dominicanewsonline.com/news/homepage/news/general/prince-charles-hails-resilience-of-hurricanebattered-dominicans/

"President Clinton says Dominica can lead way in producing clean energy." Dominica News Online website, February 6, 2018. Accessed April 1, 2018.

http://dominicanewsonline.com/news/homepage/news/general/president-clinton-says-dominica-can-leadway-in-producing-clean-energy/

${ }^{27}$ Wilkinson, Emily, John Twigg, and Roger Few. 2018. "Building Back Better: A Resilient Caribbean After the 2017 Hurricanes.” ODI Briefing note. ODI website. Accessed April 4, 2018.

https://www.odi.org/sites/odi.org.uk/files/resource-documents/12028.pdf

${ }^{28}$ See: CARICOM 2017. "Rebuilding Dominica as a Climate Resilient Nation: The Climate Resilient Execution Agency for Dominica (CREAD), Proposal from the Government of the Commonwealth of Dominica.” CARICOM website. Accessed March 1, 2018. https://resilientcaribbean.caricom.org/wpcontent/uploads/2017/11/Draft-of-DominicaG\%C3\%87\%C3\%96s-Proposed-New-Execution-AgencyCREAD-19.11.17.docx

${ }^{29}$ Mystelics. 2017. Aftermath of Hurricane Maria in Colihaut. YouTube, September 24. Accessed November 1, 2017. https://youtu.be/wqXa3MeKV2Q

${ }^{30}$ A colleague, Pablo Herrera, alerted me to similar responses to Hurricane Irma in Cuba, where men in Havana were photographed playing Dominoes in the flood waters amidst the fallout of the storm. The image provoked online debate amongst diasporic Cubans, some of whom condemned them for relaxing in a time of crisis-a prime example of "social indiscipline"; and others who praised their resilience and humour for "putting a good face on bad times." See: Weissenstein, Michael and Andrea Rodriguez. 2017. "Pic of Cubans at dominoes in Irma floodwaters sparks debate." News 1130 website, September 15, 2017. Accessed November 1, 2017. http://www.news1130.com/2017/09/15/pic-of-cubans-at-dominoes-in-irmafloodwaters-sparks-debate/

${ }^{31}$ Indeed, charity is wounding to the recipient, as Mary Douglas reminds us in her foreword to Mauss' seminal essay on the "spirit of the gift" (2002 [1950], viiii).

${ }^{32}$ See "Derek Walcott obituary.” The Guardian website, March 17, 2017. Accessed November 1, 2017. https://www.theguardian.com/books/2017/mar/17/derek-walcott-obituary 